\title{
Prevention of infectious diseases in harbour divers: how environmental parameters can help
}

\author{
Richard Pougnet ${ }^{\mathbf{1 ,}}$, Ingrid Allio ${ }^{\mathbf{1}, \mathbf{3}}$, Laurence Pougnet ${ }^{\mathbf{1}, \mathbf{4}}$
${ }^{1}$ Maritime Medicine French Society (SFMM), Brest, France
${ }^{2}$ EA 4686 Ethic Professionalism and Health, European University of Brittany, Brest, France
${ }^{3}$ Analysis Monitoring and Expertise Laboratory of the Navy, Brest, France
${ }^{4}$ Military Hospital Clermont-Tonnerre, CC41 BCRM, Brest, France
}

Professional divers should sometimes immerse in dirty waters, such as divers working in harbours. There is in Brest a military port and a repair shipyard, where divers work and may be exposed to chemical products or microorganisms. Thought, a very few studies is available on professional diver infectious diseases. Here is evidence: search on Medline database ("Diving" [Mesh] AND "Infectious Disease Medicine" [Mesh]) shows no results. It is generally accepted that divers may have cutaneous infectious diseases. A study about Pseudomonas aeruginosa infections among divers was conducted more than 15 years ago [1]. More studies are available about infectious diseases in recreational divers, mainly about external otitis [2, 3], or conjunctivitis [4]. Infections could sometimes be more serious. A case of mastoiditis was due to an immersion in seawater which contained a lot of harmful algae (bloom). A high bacterial burden could explain it [5]. Other studies showed that a high bacterial burden in water was at risk for anyone who bathe or dive in it [6]. This is especially true when water is polluted with wastes and contaminated with faeces or rubbish [7]. In 2010, in repair shipyard and in military port of Brest, some medical examinations of divers 2010 revealed infections, mainly external otitis and cutaneous infections. Were these due to polluted water? A study was conducted in Brest harbour next to the docks and Penfeld River. The studied parameters were the presence in the water of microorganisms indicating faecal contamination (Escherichia coli), and chemical elements $\left(\mathrm{PO}_{4}, \mathrm{NO}_{2}, \mathrm{NH}_{4}\right)$. These data were compared with climatic data, especially rainfall. Contamination in the Penfeld River reached an average level of $10^{3}$ CFU E. coli/100 mL. Contamination peaks could reach
$10^{4}$ to $10^{5} \mathrm{CFU}$ E. coli/100 $\mathrm{mL}$ in rainy weather or significant release. A contamination gradient appears mainly due to the position of the discharge areas in the river. There was no toxic contamination (Figs. 1, 2).

This study points out that heavy rains can lead to riverbed modifications, so that water cannot be treated before the releases in the industrial part of the harbour. Thereby, there was a risk to dive in seawater containing a high bacterial burden. Since, the divers were equipped with drysuits in the most polluted areas. Beside, this study enabled a dynamic mapping of pollution. Following this study, prevention for divers in this port was improved.

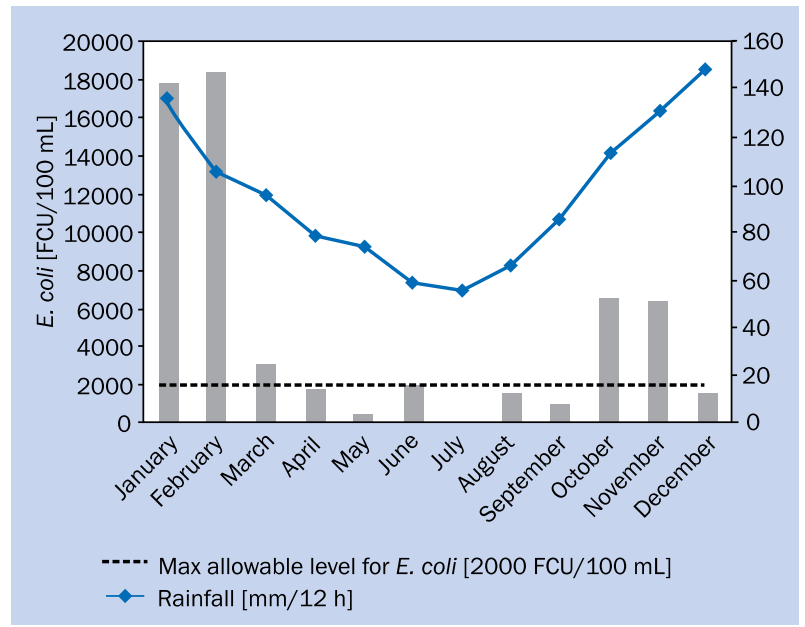

Figure 1. Relationship between rainfall and bacteriological contamination; adapted from [8] 


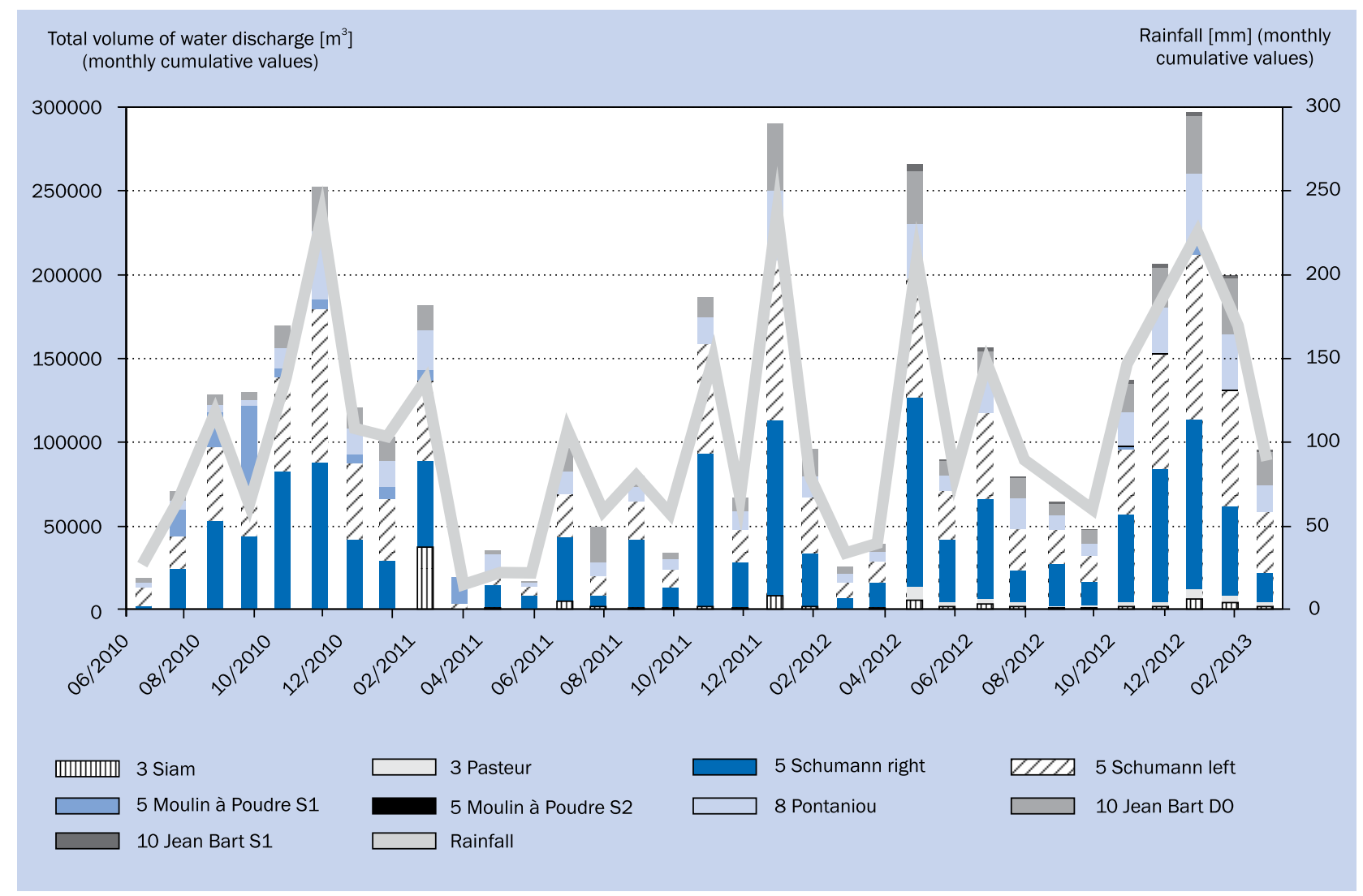

Figure 2. Relationship between releases in Penfeld River and rainfall, adapted from [8]

\section{REFERENCES}

1. Ahlén C, Mandal LH, Iversen OJ. Identification of infectious Pseudomonas aeruginosa strains in an occupational saturation diving environment. Occup Environ Med 1998; 55: 480-484.

2. Azizi MH. Ear disorders in scuba divers. Int $J$ Occup Environ Med 2011; 2: 20-26.

3. Muth $\mathrm{CM}$, Müller $\mathrm{P}$, Kemmer A. [Medical aspects of diving in the tropics]. MMW Fortschr Med 2005; 147: 28-32.

4. Olsson DJ, Grant WD, Glick JM. Conjunctivitis outbreak among divers. Undersea Hyperb Med 2008; 35: 169-174.
5. Honner S, Kudela RM, Handler E. Bilateral mastoiditis from red tide exposure. J Emerg Med 2012; 43: 663-666.

6. Mena KD, Gerba CP. Risk assessment of Pseudomonas aeruginosa in water. Rev Environ Contam Toxicol 2009; 201: 71-115.

7. Leclerc H, Schwartzbrod L, Dei-Cas E. Microbial agents associated with waterborne diseases. Crit Rev Microbiol 2002; 28: 371-409.

8. Allio I, Pougnet L, Pougnet R. Occupational risk prevention of harbour divers: contributions of methodology. The $13^{\text {th }}$ International Symposium on Martime Health, Bergen 23-26 June 2015. 